\title{
Global to regional overview of floods fatality: the $1951-2020$ period
}

\author{
Hossein Hamidifar ${ }^{1}$ and Michael Nones ${ }^{2}$ \\ ${ }^{1}$ Water Engineering Department, Shiraz University, Shiraz, Iran \\ ${ }^{2}$ Institute of Geophysics, Polish Academy of Sciences, Warsaw, Poland
}

Correspondence: Michael Nones (mnones@igf.edu.pl)

\begin{abstract}
Floods are among the most devastating natural hazards. Human interferences along with climate change cause a lot of human and financial losses every year following the occurrence of floods. In this research, flooding events that have killed more than 10 people in the 1951-2020 period have been studied, analysing the EM-DAT database. The results show that the severity of flood-related deaths is equally distributed worldwide, but present some specific geographical patterns. The flood fatality coefficient, calculated for different countries, identified that Southern, Eastern, and South-Eastern regions of Asia have the deadliest floods in the world. The number of flood events has been increasing since 1951 and peaked in 2007 , following a relatively declining trend since then. However, the number of death tolls does not follow a statistically significant trend. An examination of the number of flood events in different decades shows that the highest number of events occurred in the 20012010 decade, which corresponds to the largest precipitation anomaly in the world. The most casualties occurred in the decade 1991-2000. However, the lethality of floods has decreased over time, from 412 per flood in 1951-1960 to 67 in the 2011-2020 decade, probably as a consequence of a more resilient environment and better risk reduction strategies. In addition, a direct correlation was found between the number of flood events and the number of casualties with the world's population.
\end{abstract}

\section{Introduction}

River and coastal floods caused millions of fatalities in the past century, and the global average annual loss due to riverine floods in the past ten years was estimated at around USD 651 billion (UNDRR, 2020).

Major floods happened in the past (Berz, 1988), but, following changes in climate, land use, infrastructure and population demographics, more intense events are expected. Indeed, exposure to floods is forecasted to grow by a factor of three by 2050 owing to a surge in population and economic assets in flood-prone areas (Jongman et al., 2012). Depending on the socioeconomic scenario, human losses from flooding are projected to rise by $70-83 \%$ and direct flood damage by $160-240 \%$ relative to the 1976-2005 period, with a temperature increase of $1.5^{\circ} \mathrm{C}$ (Dottori et al., 2018). To adequately manage such scenarios and plan risk reduction strategies, understanding river flooding and the associated multi-scale impacts are critical, especially in a changing climate characterized by more frequent extreme events (Nones and Pescaroli, 2016; Tellman et al., 2021; Wasko et al., 2021).

River floods occur when a river overtops its banks, potentially causing bank failures, and inundates adjacent areas. The expected impact floods have on society and the environment, often termed flood risk, results from the superposition of three components and the associated processes, which tend to be interlinked (e.g., Kron, 2005; Barendrecht et al., 2017; Zhou et 
.

al., 2017). These components results from multiple processes (Merz et al., 2015), and are usually summarized as "hazard", meaning the flood process frequency and magnitude; "exposure", which accounts for the elements at risk, such as population, ecosystems and infrastructure; and "vulnerability", i.e., the susceptibility of the elements at risk, like loss of lives, livelihoods and other aspects of well-being that are adversely affected by flooding events (Turner et al., 2003; UNISDR, 2019). Generally, riverine flood hazard is a consequence of high-rainfall processes in the atmosphere, run-off generation in the catchment, and flood waves travelling through the river network. Exposure depends on anthropogenic aspects, such as the use of floodplains, population density and economic development. Vulnerability is shaped by human adaptive influences, such as private precautions, education level, early warning or crisis management strategies, adaptive plans.

It is well known that human activities affect flood processes broadly (Chen et al., 2012; Ross and Chang, 2020). Indeed, alteration of river basin land use land cover is transforming run-off generation and transport processes, and human-driven climate change can enhance heavy precipitation and affect snow-melt or catchment wetness, thus additional influencing flood risk (Blöschl et al., 2015). Levees, flood retention infrastructures like check-dams, and early warning systems are potentially effective in reducing flood risk, but can also fail unexpectedly, thereby surprising affected communities and amplifying the flood damage (e.g., Liu et al., 2019; Nones, 2019; Manfreda et al., 2021).

Although various methods have been proposed to reduce the damage and severity of floods, proper management as well as accurate and fair distribution of facilities require a deep understanding of flood vulnerability both at global and local scale. Indeed, many uncertainties and complexities are intrinsically present in flood-related issues (Altez and Revet, 2005; Petrucci, 2021), involving large uncertainty in flood prediction modelling. However, good estimates could be derived from past records and available statistics, helping in developing improved risk reduction plans to fit specific global and regional settings. The availability of comprehensive and up-to-date databases of flooding events (e.g. EM-DAT, Global Flood Monitor, Global Flood Database) permit to gain new insights on the effects of floods in the past, as well as on the society response. The development of these databases is also taking advantage of social media, which allow for getting data very rapidly, using humans as sensors (e.g., smartphones, wearable devices, etc.), but involving large biases such as language and geographical distribution of social networks (de Bruijn et al., 2019).

In this study, disastrous floods are defined as those with devastating consequences and causing more than 10 fatalities. Globally, those happenings are prevalent, as more than 10,000 significant events were identified in the 1951-2020 period in the database Emergency Database (EM-DAT, www.emdat.be). As described in Section 2, the analysis was limited to events reporting between 10 and 10,000 casualties, showing, globally, an uneven distribution in both the number of events and the total deaths (Section 3). The major prevalence of events in Asia is also one of the causes of the very high death tolls in those regions, but the local conditions (population density, socio-economic situation) are also playing a major role (see Section 4).

\section{Materials and Methods}

In this study, flood events collected in the Emergency Database (EM-DAT) were used. This database contains basic data on the occurrence and effects of more than 22,000 disasters in the world from 1900 to the present. The database is gathered from 
various sources, including UN agencies, NGOs, insurance companies, research institutes and media agencies. For the present study, data referring to the last 70 years (period 1951-2020) were downloaded from the database and post-processed.

To better understand the status of available data, a classification was first made based on the number of events and the number of fatalities. Based on this, five categories were considered: less than 10, 10 to 99, 100 to 999, 1,000 to 9,999, and more than 10,000. The frequency of occurrences as well as the number of fatalities during the period of 1951-2020 are shown in Figure 1. According to Figure 1a, it can be seen that the highest frequency (about 51\%) belongs to the category of 10-99 fatalities and the lowest frequency (about $0.15 \%$ ) belongs to the category of more than 10000 events. On the other hand, Figure $1 \mathrm{~b}$ shows that flood casualties in the category of less than 10 people include a small part (less than $0.2 \%$ ) of the total casualties, and therefore, in the present study, this category of data is not considered in the analysis. This also corroborates the research hypothesis to focus only on disastrous flood, namely on events causing more than 10 fatalities. As a result, only incidents with casualties between 10 and 9999 have been included in the analysis of the present study.

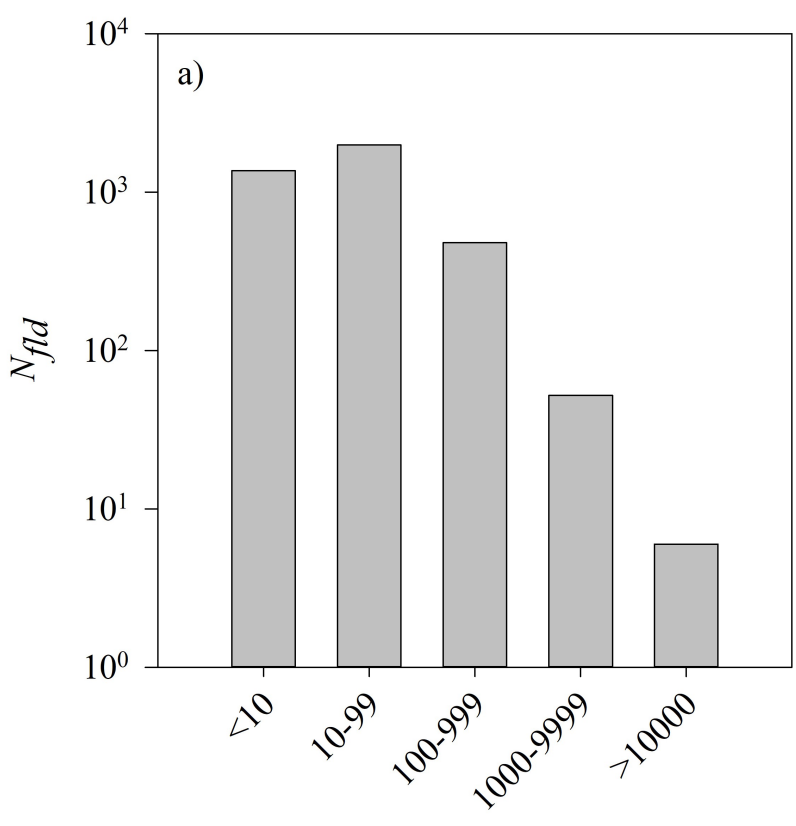

Category

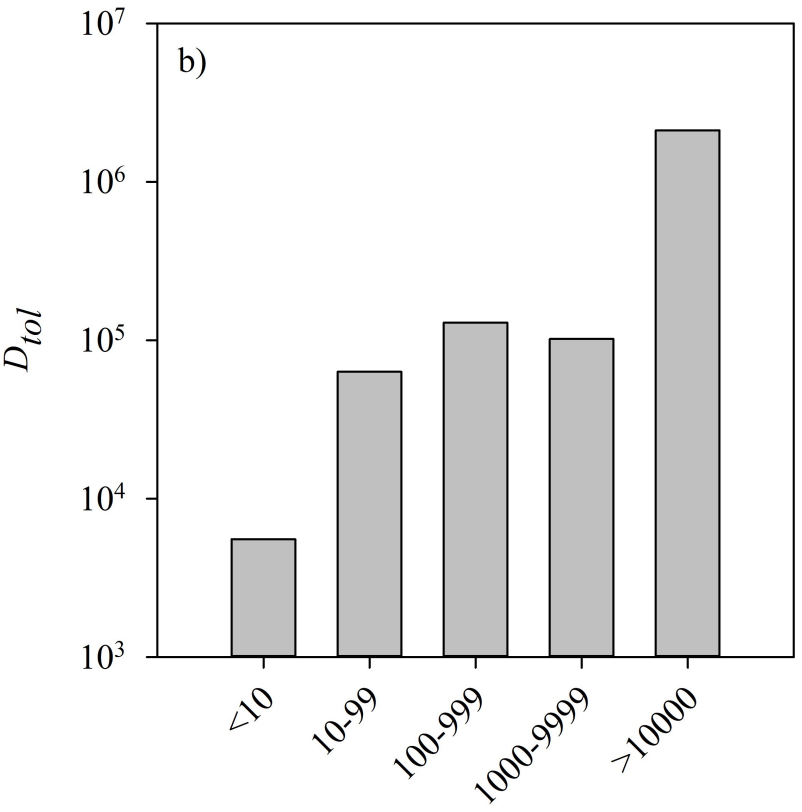

Category

Figure 1. Classification of EM-DAT data according to a) number of flood events; b) number of death tolls.

Since the number of events with casualties of more than 10000 people is small (six cases, 1), and the number mentioned in the sources regarding the casualties of these events is mainly mixed with casualties due to incidental events, this category has been investigated on a case-by-case basis, as briefly reported in the following. 


\subsection{China 1954 Flood}

In the summer of 1954, following heavy and continuous rains in the Yangtze River Basin, a huge flood occurred, causing the most damages in the Hubei Province. Even if the 1931 event was more disastrous (Wang and Plate, 2002), official agencies reported more than 30,000 death toll (Zong and Chen, 2000). However, in some other reports, including casualties from accidents and cascading events such as diseases following the flood, this number has reached up to 200,000 people. A total of more than 18 million people was strongly affected by this flood event.

\subsection{China 1959 Flood}

In 1959, a major flood in Eastern China caused the Yellow River to overflow. It is estimated that 2 million people were killed. Because of the lack of detailed information, it is very difficult to estimate how many people died as a direct result of the flood, and how many fatalities were caused by the great famine that followed (www.statista.com/statistics/267746/number-of-deathsglobally-due-to-major-flooding).

\subsection{Bangladesh (East Pakistan) 1960 Flood}

Despite its relatively small area, Bangladesh (previously known as East Pakistan) is one of the most populated regions in the world, as well as one of the poorest (Dasgupta, 2007). Moreover, this country is very disaster-prone, with floods being the second most frequent occurrence after windstorms, and the one that caused the greatest losses.

The floods of 1960 is a clear example of disastrous events that happened in the region, as very intense precipitations caused an inundation of about $20 \%$ of the country area. As a result, 10,000 people were killed, while many others were displaced.

\subsection{Bangladesh 1974 Flood}

Heavy rains in Bangladesh in the late spring of 1974 caused very severe flooding events in the area around the Brahmaputra, Ganges, and Meghna rivers, killing at least 28,700 people and affecting more than 50\% of the entire population of the country (Paul and Mahmoud 2016). Of course, following this flood, other incidents took place in this country, including a severe famine (Clay, 1985). Very probably the number of casualties are much higher that the one reported in official sources, as the affected areas were very poor.

\subsection{China 1975 Flood}

In August 1975, central China was impacted by very high rainfall events, with statistics reporting $830 \mathrm{~mm}$ of precipitations in six hours, and about 1,000 mm cumulatively in three days (Yang et al., 2017). Triggered by such extreme rainfall, a massive flood occurred, killing more than 20,000 people. More than 10 million people also lost their shelters in this disaster. During the event, several dams were broken, including the Banqiao Dam, 118 meters high and 492 million cubic meters of reservoir, which were in the path of the flood, and led to an increase in casualties, not officially reported. The height of the wave formed by the breaking of this dam reached 10 meters, which was moving downstream at a velocity of $50 \mathrm{~km} / \mathrm{h}$ (Liu et al., 2019). 


\subsection{Venezuela 1999 flood}

In December 1999, heavy rains caused a severe flood in Venezuela. About $200 \mathrm{~mm}$ of rain fell in two days in the Vargas area, which led to floods, landslides and debris flows, killing about 30,000 people. Many bodies were never found due to transfer to the sea. During this event, about 20 million $\mathrm{m}^{3}$ of sediment was transported downstream from 24 watersheds upstream of Vargas Beach and spread over an area of about $200 \mathrm{~km}^{2}$ (?). Subsequent estimates showed that a debris flow with a velocity greater than $10 \mathrm{~m} / \mathrm{s}$ was the main cause of high casualties in this disaster (Takahashi et al., 2001; Wieczorek et al., 2017).

\section{Results}

The spatial distribution of the frequency of flood and the flood fatality indices are shown in Figures 2a and 2b, respectively. Due to the large differences between the upper and lower bounds of data from a statistical point of view (the average values of flood events frequency, $N_{f l d}$, and the number of death tolls, $D_{t o l}$, among the countries studied are 18.4 and 21.8, respectively, with standard deviations of 35.9 and 8070.7, respectively), and to better represent the differences between different countries, the logarithm to base 10 of these parameters, i.e., $\log _{10}\left(N_{f l d}\right)$ and $\log _{10}\left(D_{t o l}\right)$ are used for reporting flood frequency and death tolls in Figures 2a and 2b, respecttively. As can be seen, the maximum number of flood events correspond to India, China, Indonesia, Pakistan, Brazil and Vietnam, with 270, 247, 118, 98, 92 and 76 events, respectively. However, the highest fatalities correlated to flooding events were reported in India, China, Pakistan, Bangladesh, Japan and Iran, with 75,355, 53,966, 15,192, $14,238,8,033$ and 7,883 death tolls, respectively.

Only three countries appear in both lists: India, China, and Pakistan, which are in the top 5\%, meaning that some countries are more vulnerable to floods than others. For example, Bangladesh, Iran and Japan, although ranked $9^{\text {th }}, 10^{\text {th }}$ and $18^{\text {th }}$ in terms of the number of floods, are ranked $4^{\text {th }}, 5^{\text {th }}$ and $6^{\text {th }}$, respectively, in terms of the total number of casualties. On the other hand, Indonesia, Brazil and Vietnam, which are ranked $3^{\text {rd }}, 5^{\text {th }}$ and $6^{\text {th }}$ countries with the highest number of flooding events, respectively, are ranked $9^{\text {th }}, 8^{\text {th }}$ and $10^{\text {th }}$ among all countries in terms of total number of victims.

To compare the human losses caused by in different countries, the fatality coefficient of floods is calculated by dividing the total number of death tolls by the number of flood events for each country, and its spatial distribution is shown in Figure 3.As can be seen in Eq.(1), to better represent the differences at the global level, a log scale is used in Figure 3 as already made in Figure 2.

$C_{f a t}=\log _{10}\left(\frac{D_{t o l}}{N_{f l d}}\right)$

In Eq.(1), $C_{f a t}$ is the fatality coefficient of floods for each country. As can be seen, the Netherlands, Lebanon, Yemen, Hungary, India, and Somalia have the highest fatality coefficient in the world (top 5\%). It should be noted that, for Netherlands, Lebanon and Hungary, only one flood event was recorded during the studied period, which occurred in 1953, 1955 and 1970, respectively, and no other floods with more than 10 deaths have been recorded in these countries since then. The countries of 
Table 1. Summary of flooding events causing more than 10,000 fatalities during the period 1951-2020.

\begin{tabular}{|c|c|c|c|c|c|}
\hline Year & Country & Basin & $\begin{array}{l}\text { Estimated } \\
\text { fatalities }\end{array}$ & $\begin{array}{l}\text { peak discharge } \\
\left(\mathrm{m}^{3} / \mathrm{s}\right)\end{array}$ & Descriptions \\
\hline 1954 & China & Yangtze River & 30,000 & 66,800 & $\begin{array}{l}\text { The discharge was measured at the Yichang } \\
\text { station, whose annual average flow was only } \\
14,300 \mathrm{~m}^{3} / \mathrm{s} \text { (Jinrong and Zhongshu, 1986). }\end{array}$ \\
\hline 1959 & China & Yellow River & $2,000,000$ & 7,680 & $\begin{array}{l}\text { The discharge is based on measurements at } \\
\text { Huayuankou station (van Maren et al., 2006). } \\
\text { About } 35 \% \text { of the country area was inun- } \\
\text { dated during the event (Monowar Hossain et al., } \\
2008 \text { ). }\end{array}$ \\
\hline 1960 & Bangladesh & Many regions in the country & 10,000 & - & $\begin{array}{l}\text { About } 20 \% \text { of the country area was inundated } \\
\text { due to this event. Examination of available re- } \\
\text { sources shows that the fatalities reported for } \\
\text { this event are mainly due to several tidal waves } \\
\text { following a severe cyclonic storm (e.g.,Dunn, } \\
\text { 1962; Sheehan and Hewitt, 1969; Frank, 1971; } \\
\text { Rasid and Paul, 1987; Moniruzzaman et al., } \\
\text { 2018) }\end{array}$ \\
\hline 1974 & Bangladesh & $\begin{array}{l}\text { Brahmaputra, Ganges, and } \\
\text { Meghna rivers }\end{array}$ & 28,700 & 50,700 & $\begin{array}{l}\text { During this event, } 16 \text { major rivers were above } \\
\text { the danger level for July and August. The dis- } \\
\text { charge is based on measurements at the Ba- } \\
\text { hadurabad gauging station (Mirza, 2003). }\end{array}$ \\
\hline 1975 & China & Nv River & 20,000 & 79,000 & $\begin{array}{l}\text { The discharge is estimated downstream of the } \\
\text { Banqiao Reservoir and is the largest outburst } \\
\text { flood of a man-made dam (Liu et al., 2019). }\end{array}$ \\
\hline 1999 & Venezuela & $\begin{array}{l}\text { Naigauta, Quebrada Seca, San } \\
\text { Julian, Camuri Chico, El Cojo, } \\
\text { Galipan, Guanape, Osorio, } \\
\text { Piedra Azul, Cerro, Camuri } \\
\text { Grande, and Uria Rivers }\end{array}$ & 30,000 & 1,670 & $\begin{array}{l}\text { The discharge is estimated for the Uria River. } \\
\text { For the Cerro Grande and Camuri Grande } \\
\text { rivers, the peak discharges are estimated at } \\
1,230 \text { and } 900 \mathrm{~m}^{3} / \mathrm{s} \text {, respectively (Lopez et al., } \\
2003 \text {; Nakagawa, 2003). }\end{array}$ \\
\hline
\end{tabular}




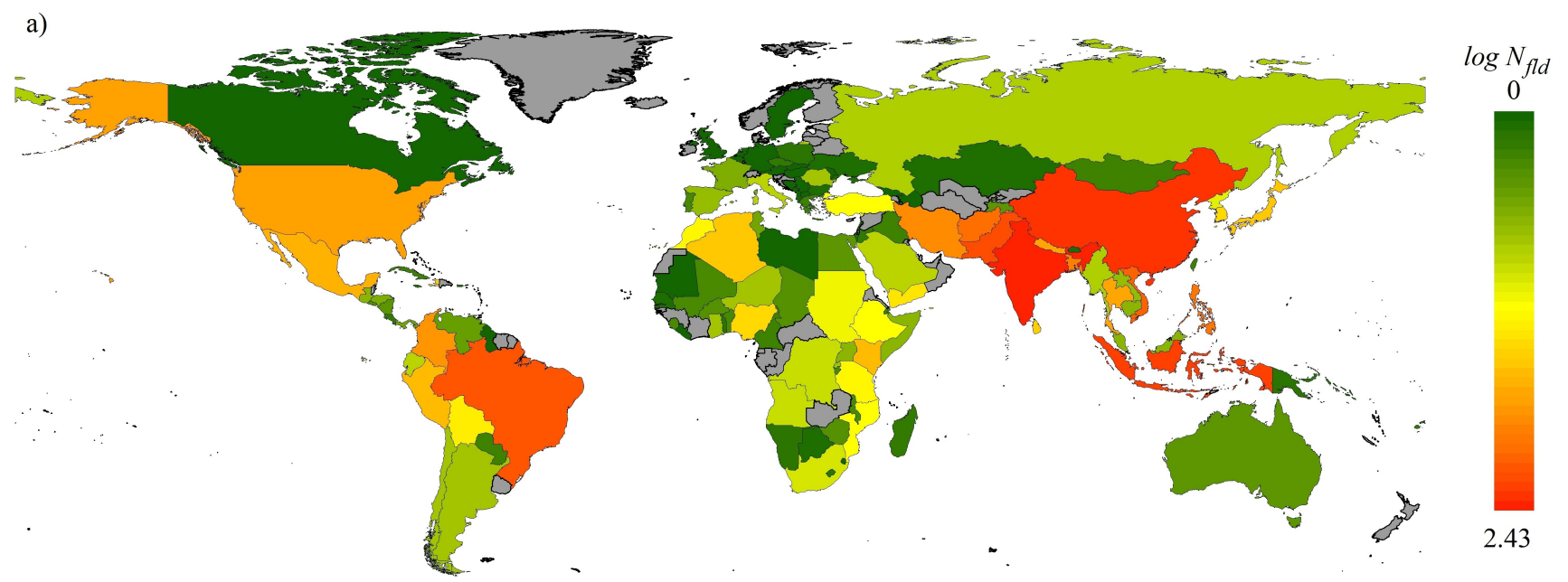

b)
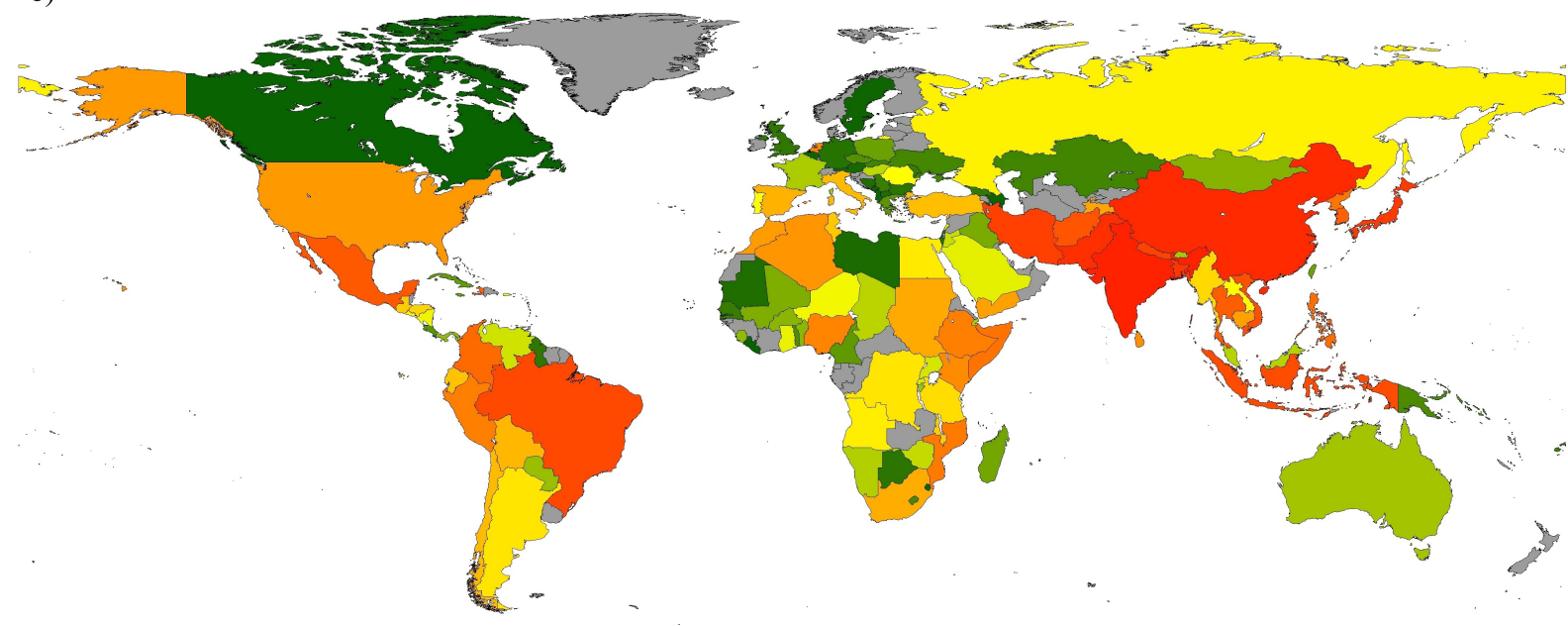

Figure 2. Global distribution of a) flood frequency; b) flood fatality index. The areas in grey are those countries having less than 10 death tolls/event during the study period.

Liberia, Canada, Albania, Azerbaijan, Belgium, Mauritius, Serbia, Montenegro, Swaziland (Eswatini), and Sweden, for which only one flood event was recorded during the studied period, are at the bottom of this list (bottom 5\%).

From the analysis it is possible to note that countries in Southern, South-Eastern and Eastern Asia have the highest number of floods worldwide, with 651, 367, and 349 events, respectively. Also, Northern Europe, Russia, Australia and New Zealand, respectively with 2, 3, 6 and 8 events, have the lowest number of happenings among different regions of the world. In terms of the number of flood death tolls, Southern Asia, Eastern Asia, and South-East Asia regions, with 127,738, 69,381, and 23,930 


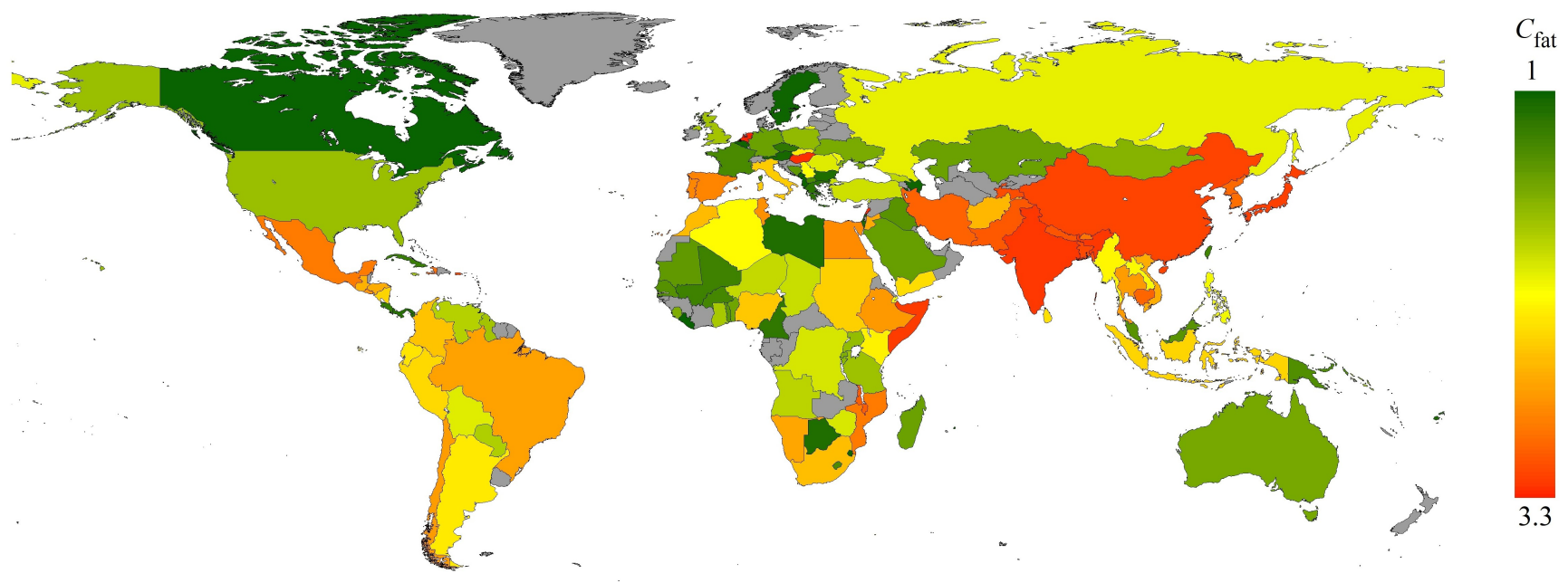

Figure 3. Global distribution of the flood fatality coefficient. The areas in grey are those countries having less than 10 death tolls/event during the study period.

death tolls, are the most impacted, while Northern Europe, Russia, and Melanesia regions, with 45, 141, and 187 death tolls, have the lowest number of casualties during the studied period.

As an example of geographical disparities, one can observe that flooding occurred in the Asian continent lead to higher average human casualties, which could be due to the very high population density (more than 4 times that of Europe and more than 40 times that of Oceania, following the www.worldpopulationreview.com data), as well as to the poverty of some of the major impacted countries. A further discussion about the effects of socio-economic conditions on flood-related fatalities is reported in the following section.

To provide a global overview of flood-related hazard, Figure 4 shows the spatial distribution of the number of flooding events and the number of death tolls for different continents. As can be seen, Asia has $76.9 \%$ of floods death tolls with $57.9 \%$ of flood events. In contrast, about $11.2 \%$ of the total casualties due to floods were reported in the Americas, characterized by $18.7 \%$ of events, about $9.2 \%$ to the African continent with $18.3 \%$ of casualties, about $2.6 \%$ to the European continent with $4.5 \%$ of flood events, and finally Oceania accounts for $0.7 \%$ of all human casualties with $0.7 \%$ of flood events.

Figure 5 shows the temporal variations in the number of flooding events, as well as the number of death tolls during the 1951-2020 period. As can be seen, the number of flood events from 1951 to 2007 almost had an increasing trend, and then followed a decreasing path. However, the number of death tolls does not follow a certain trend and fluctuates a lot during the studied period. Figure 5c and 5d shows the 5-year moving average of flood events and total deaths, respectively, normalized by their average values.

While clear increasing and decreasing trends can be observed for the normalized number of flood events over time before and 

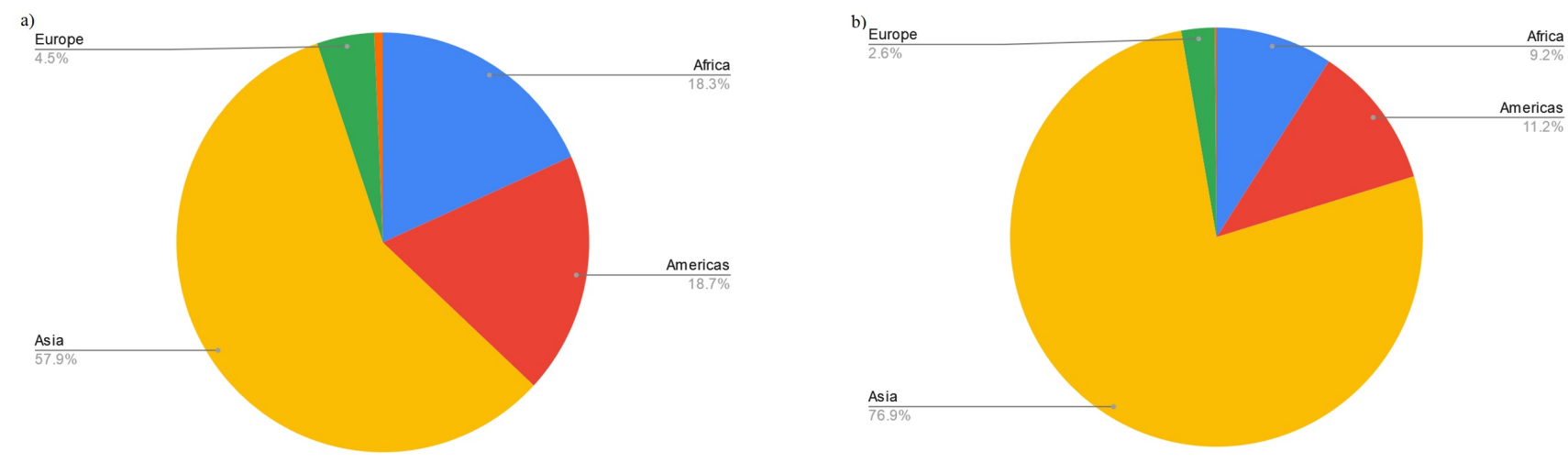

Figure 4. Percentage distribution of a) total flood events; b) total death tolls in the different continents.

after 2007, respectively, the moving average (Figure 5d) does not reveal a clear trend over time. Rather, periods of normalized death tolls less than unity and greater than unity can be generally observed before and after 1980, respectively. Nevertheless, during the last three years of the study period, the normalized death tolls are below the long-time average losses.

To evaluate the long-term trends, in Figure 6 these variations are depicted over different decades. As can be seen, the highest number of flood events, with 735 cases, is related to the decade 2000-2010. Such a high number can be related to the most positive annual rainfall anomaly (about $+27.5 \mathrm{~mm}$, Figure $6 \mathrm{~b}$ ) in the world during the study period. In the last decade (20102020), the number of flood events has dropped to 694. Although this decrease can be promising, it should be noted that the average number of flood events in the period 2000-2020 is about three times higher than the corresponding average in the period 1951-2000. On the other hand, the number of death tolls, after an increasing trend from the beginning of the period, reached its peak in the 1990-2000 period and has decreased since then.

To have a clearer picture of the temporal variations of flood loss intensity, the average number of casualties per flood event for each decade is given in Figure 7c. As can be seen, despite the increase in the number of flood events (Figure 6a) as well as the number of death tolls (Figure 6c) in recent decades, the number of death tolls per event shows a decreasing trend that could be due to increased warning measures and safety levels.

\section{Discussion}

To evaluate the role that anthropic pressure can have on flood trend, we examined the relationships between number of flood events, floods fatality and world population as shown in Figure 7. Figures $7 \mathrm{a}$ and $7 \mathrm{~b}$ show the variations in the number of flooding events and the number of casualties against the total world population, respectively, considering different decades. It can be seen that there is a direct correlation between the number of flood events and the number of casualties with the world's population. In other terms, as expected, to an increase of population corresponds a higher number of casualties. This reflects 

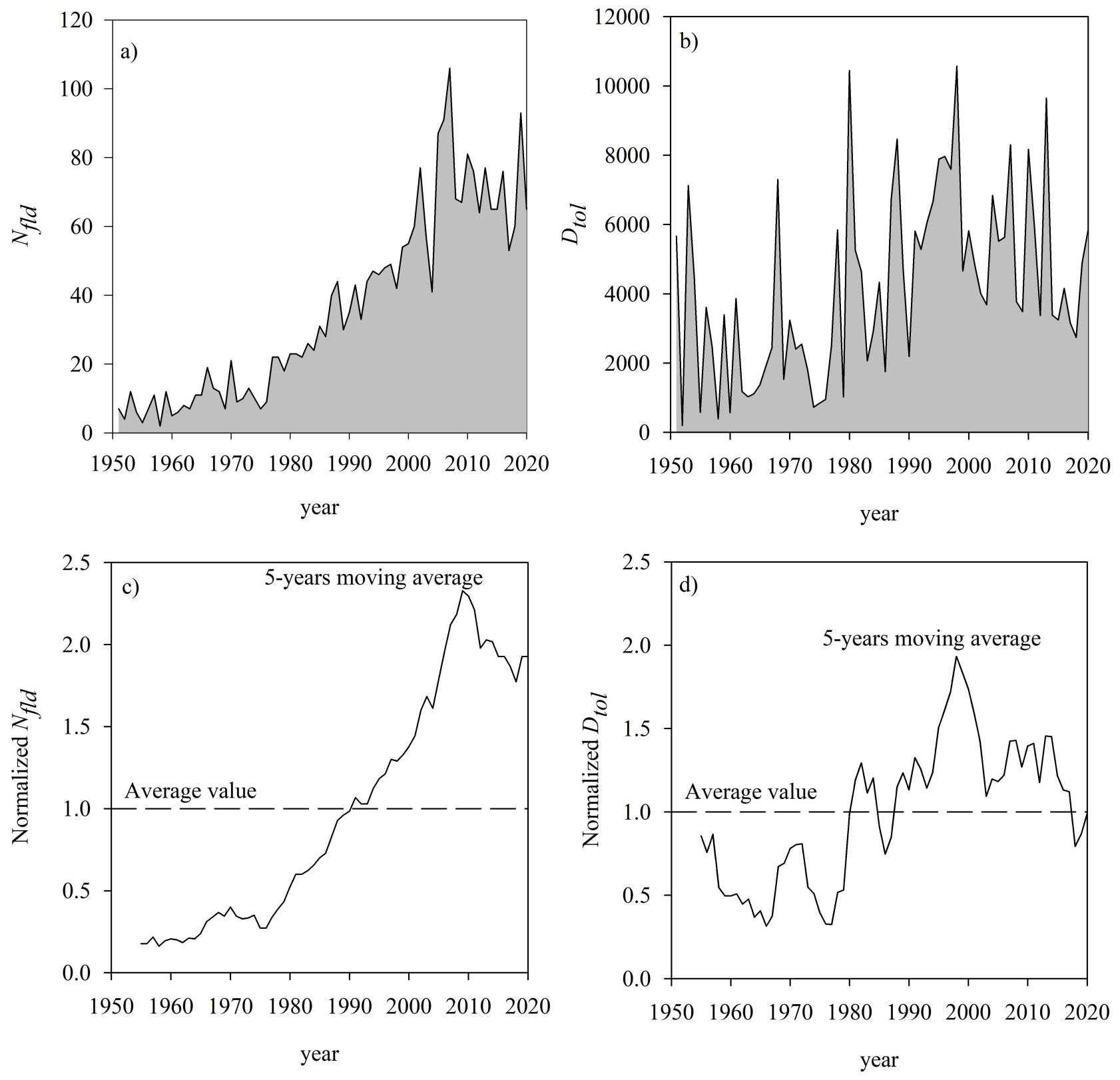

Figure 5. Temporal variations in a) number of flood events; b) death tolls.

the role of anthropogenic activities on natural processes such as floods (e.g., ?; Kiss and Blanka, 2012; Stuart-Smith et al., 2021; Tellman et al., 2021).

It is worth noting that the correlation between humans and nature, as well as the potential effects of anthropogenic alterations in many river corridors worldwide were the focus of several studies. For example, artificial channelization has changed the 
https://doi.org/10.5194/nhess-2021-357

Preprint. Discussion started: 1 December 2021

(c) Author(s) 2021. CC BY 4.0 License.

\section{(c) (1)}

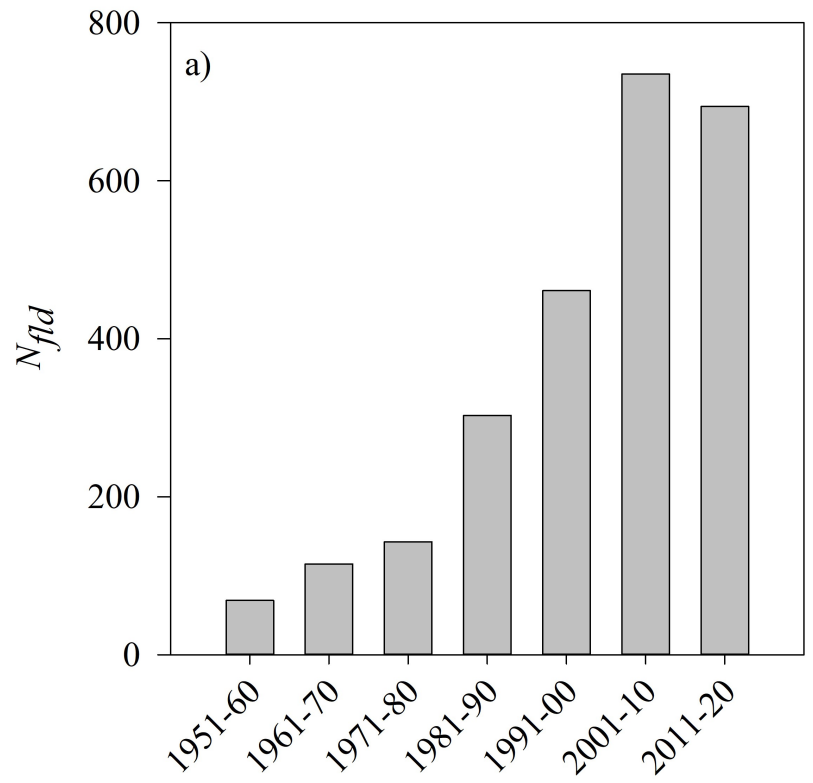

Decade

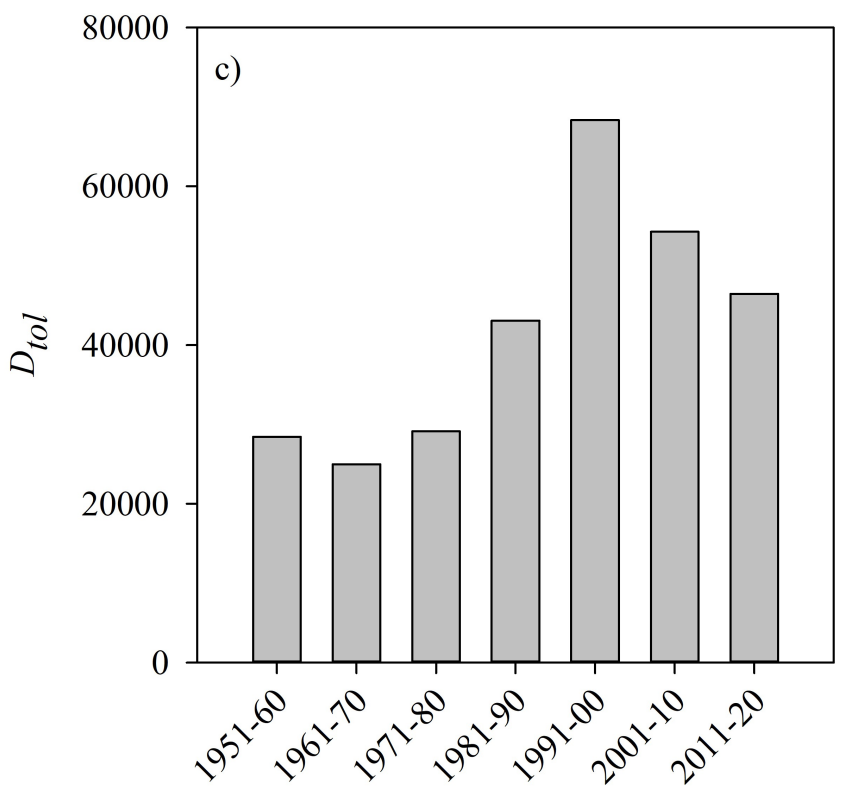

Decade
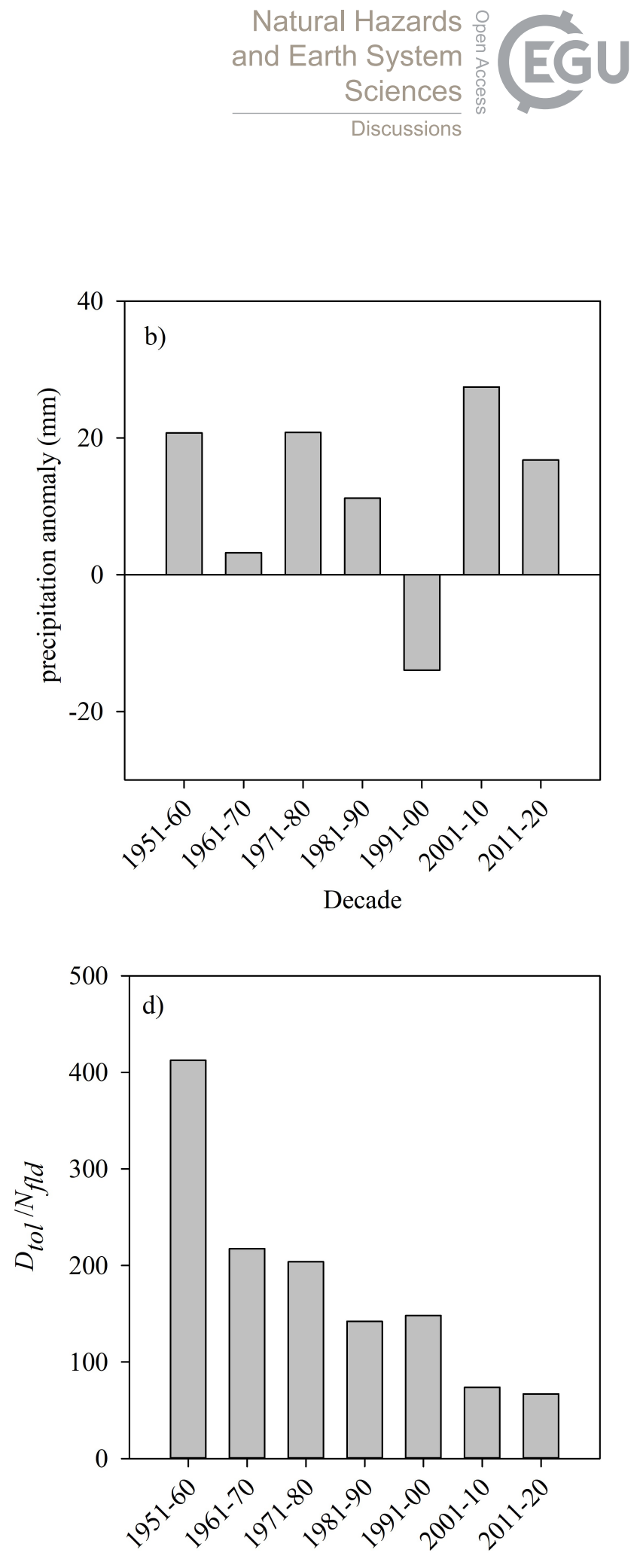

Decade

Figure 6. Decadal variations of a) number of flood events; b) anomaly of global precipitation; c) total death tolls; d) death tolls per event. 

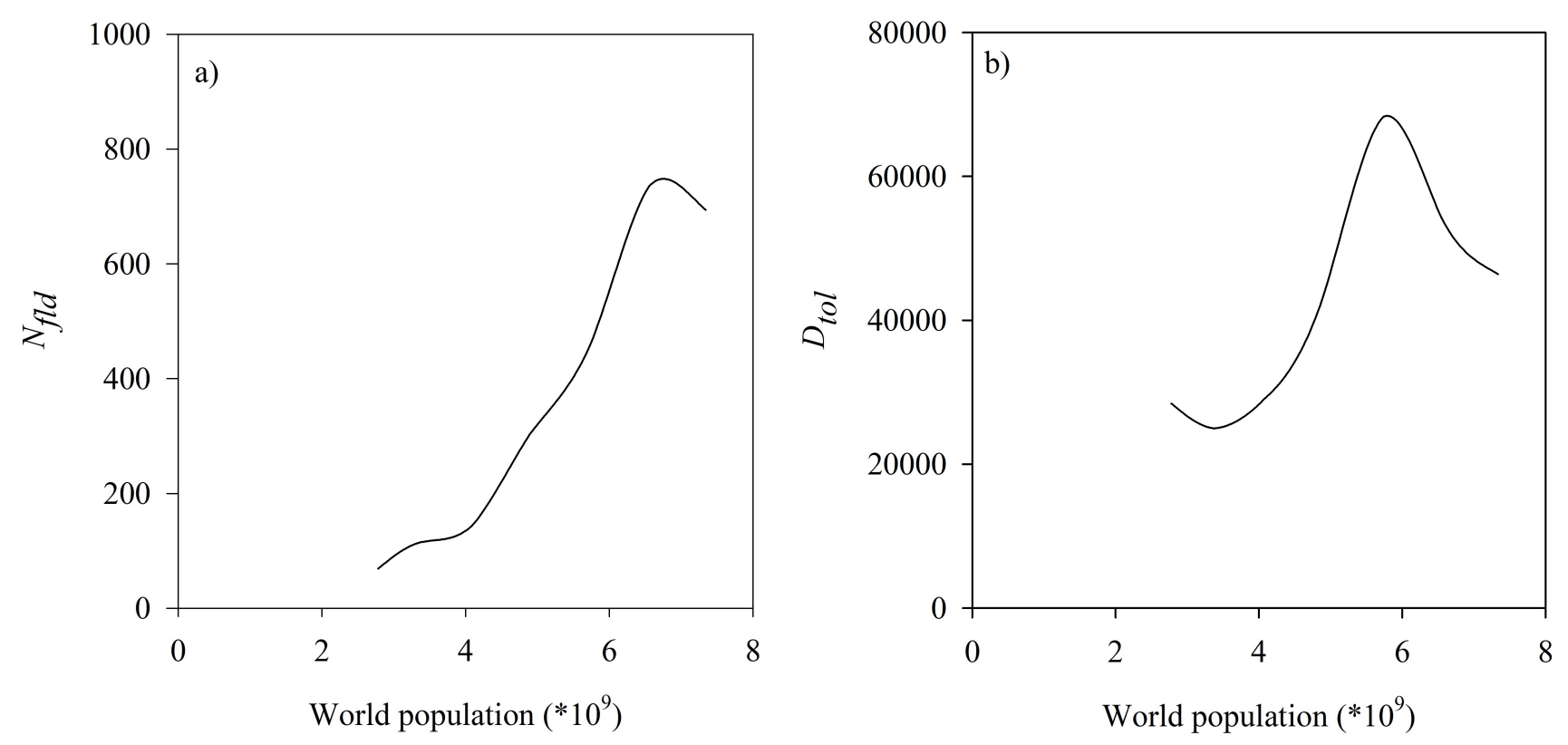

Figure 7. Variations of a) number of flood events, and b) total death tolls against world population.

stage-discharge relationship and accelerated the rate of land loss in the Mississippi River delta (USA), and consequently has led to the need for more investment to deal with floods in the region (Criss and Shock, 2001; Pinter et al., 2008; Munoz et al., 2018). Another example is the increased flow velocity and flood level for a given discharge due to construction of narrow levees along the American Wisconsin River, which caused damages especially during larger magnitude events (Gergel et al., 2002).

Climate change is further stressing the need for addressing flood risk combining anthropogenic and natural drivers (Bronstert, 2003; Albright and Crow, 2019). It has been proved that the increase of the global temperature is fostering an increase in flood risk (e.g., Yang et al., 2012; Hirabayashi et al., 2013; IPCC, 2021). As human activities are the major driver for such a growing trend in temperature, it could be concluded that humans are at the basis of an increase in the risk of floods. Moreover, the impact of socio-economic development on the increase of flood casualties cannot be ignored (Barredo, 2009; Tanoue et al., 2016). For example, as population density increases in areas at high risk of flooding, the number of flood casualties is expected to increase (Tellman et al., 2021).

In addition to the previous physical drivers, it must be stressed that a more connected world is driving to an increased and faster access to information and data, which play a major role in detecting trends of flood events and related damages (e.g., Tanoue et al., 2016; de Bruijn et al., 2019). However, such an increasing availability of data does not mean, per se, more scientifically sound information: as pointed out by (Altez and Revet, 2005), there could be cases were official reports are very uncertainty in 
terms of number of fatalities, especially in the hardly accessible areas.

Figure 8a shows the changes in the number of casualties versus the number of flood events for the period 1951-2020. As can be seen, the number of casualties is directly related to the number of flood events by Eq. (2) with a correlation coefficient $\mathrm{R}^{2}$ of 0.92 . This shows that if the number of flood events can be reduced, it can be hoped that the number of casualties will be reduced as a result. Planting more trees and hedges to increase water absorption, dredging rivers, retention basins, create sponge cities, green roofs, permeable pavements, restoring rivers to their natural courses, using water butts to collect rainfall, and de-synchronizing peak flows from tributaries are among the possible strategies that can be implemented to reduce flood risks.

$D_{t o l}=25.45\left(N_{f l d}\right)^{1.30}$

To determine the variations in the number of events and the number of casualties and its relationship with the economy in different countries, the changes in the number of events and the number of casualties against GDP (Gross Domestic Product) per capita are shown in Figures 8b and 8c, respectively. As can be seen, the number of flood events per area is directly related to GDP per capita. This suggests that many countries focus only on GDP growth and ignore other changes such as increased flooding due to deforestation as well as rapid urbanization rate (Trinh and Quoc, 2017; Nzunda and Midtgaard, 2017). Therefore, there are contradictions in increasing GDP and its side effects such as increased floods that should be considered by decisionmakers.

Although a higher level of safety measures is expected in countries with higher GDP per capita, exploring the variations in fatality coefficient against the per capita GDP shows that fatality coefficient is not strongly correlated with the GDP per capita, and follows an almost constant trend with an average value of 1.68. Those global-scale results are somehow counter-intuitive, as a few previous researches, focused on specific case studies, have shown that flood-induced death rates (fatalities per million people) and flood-affected rates decreased with GDP growth per capita (Larsen et al., 2006)Larsen06 Larsen; Hu et al., 2018), and also low education can be considered an intrinsic risk factor for flood mortality (Yari et al., 2020).

Figure 9 shows the ratio of flood-related deaths to population for different countries. As can be seen, Haiti, Bhutan, Nepal, Djibouti, Puerto Rico, Somalia, Tajikistan, Afghanistan, the Netherlands, Saint Vincent and the Grenadines have the highest mortality rates. All of these countries, with the exception of the Netherlands and Puerto Rico, have a GDP per capita of less than US $\$ 10,000$, and are therefore among the poorest countries in the world.

Providing relationships between different parameters can be effective in models for predicting and estimating flood losses (Ward et al., 2013). Therefore, in this study, an attempt was made to establish relationships between the number of flood events, flood losses, number of events per unit area, fatality coefficient and population.

Figures 10a-c show the variations in the number of flood events, the number of casualties, and the fatality coefficient against the population of the country. As can be seen, power relations can be fitted between these parameters with $\mathrm{R}^{2}$ as $0.85,0.89$, and 0.15 , respectively. Figure 10d shows the variations in the number of flooding events per unit area versus the population 

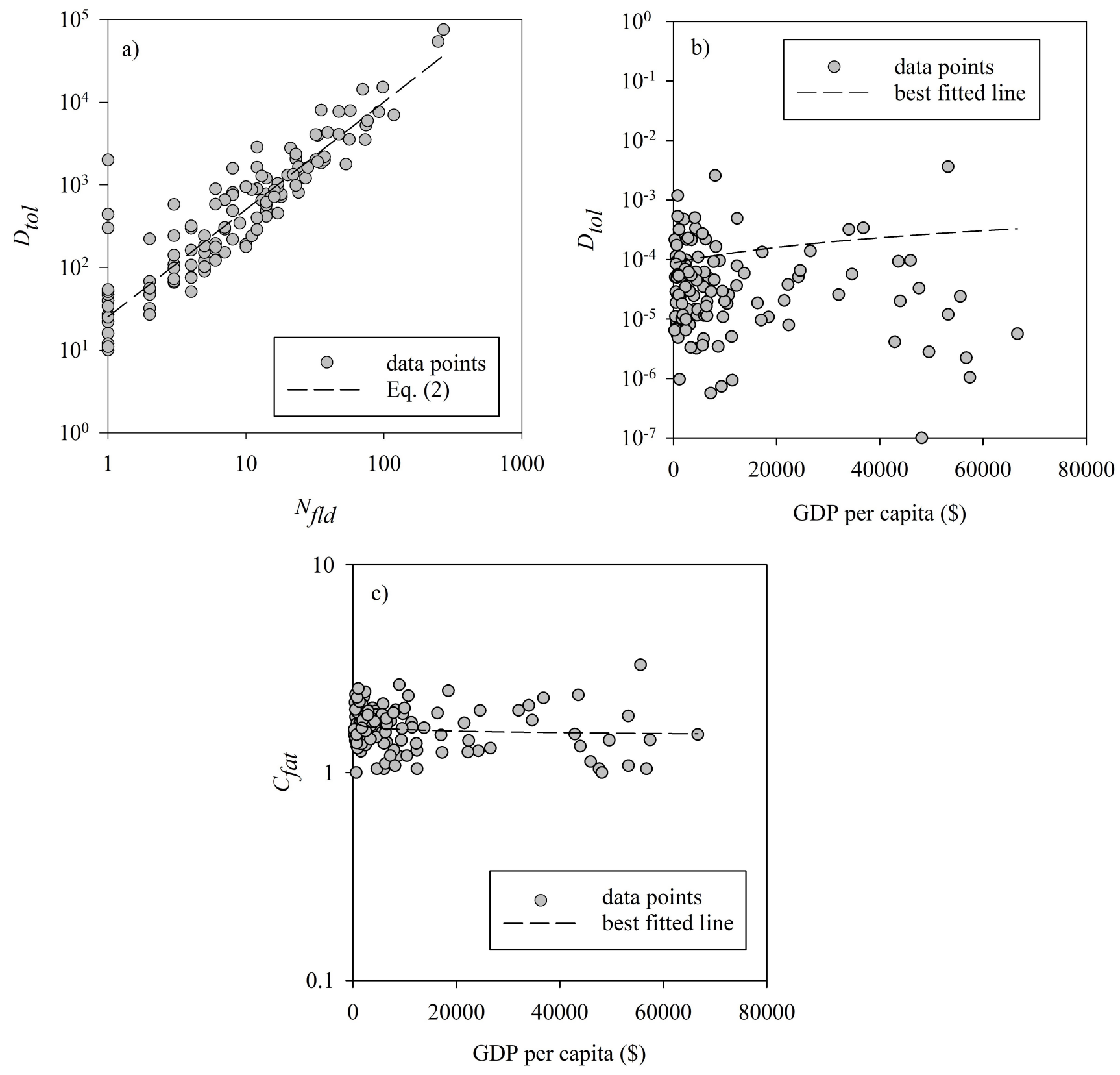

Figure 8. Variations of a) total death tolls against number of flood events; b) number of flood events per unit area against GDP per capita; c) fatality coefficient against GDP per capita.

density for each country. Using the data plotted in this figure, a power relationship can be fitted between the number of events per unit area and the population density, obtaining a correlation coefficient $\mathrm{R}^{2}$ of 0.65 . 


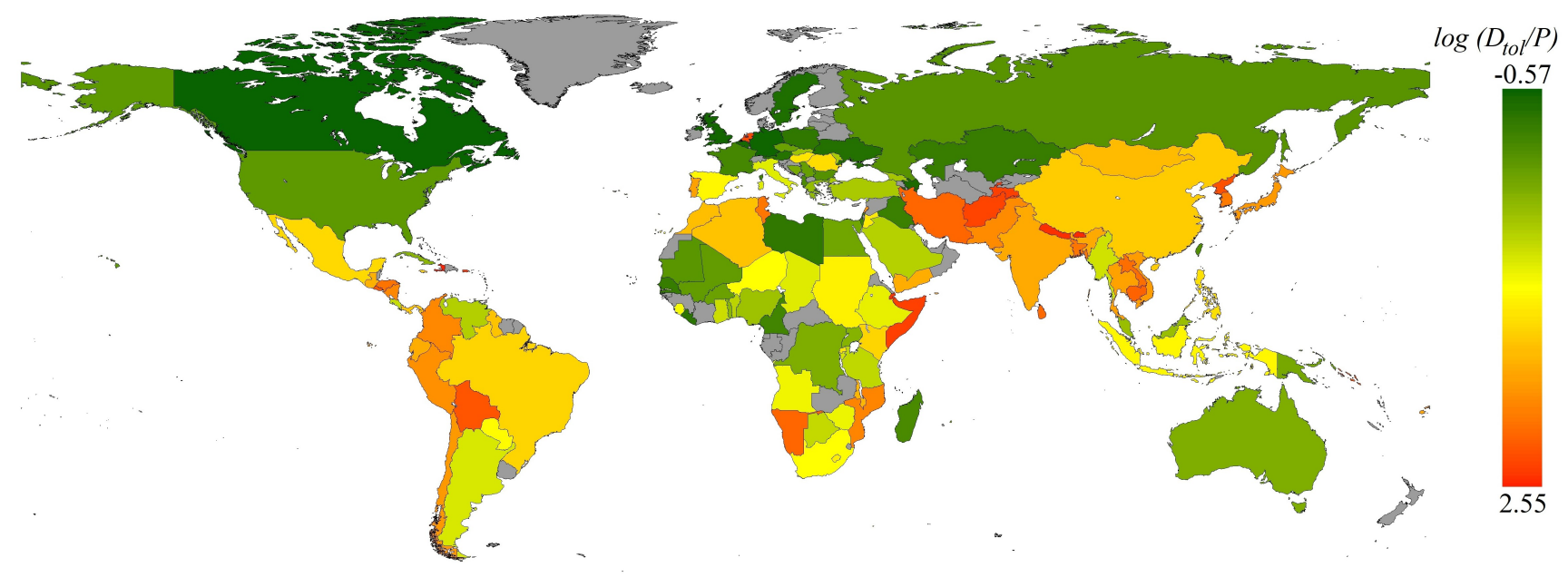

Figure 9. Distribution of the ratio of total death tolls to country population. The areas in grey are those countries having less than 10 death tolls/event during the study period.

$N_{f l d}=1.32 P^{0.73}$

$D_{t o l}=15.79 P^{1.15}$

$C_{f a t}=1.41 P^{0.06}$

$240 N_{f l d} / A=1.28 \times 10^{-6}\left(P_{d}\right)^{0.90}$

In the ebove equations, $P$ and $A$ are population (in $10^{6}$ persons) and area (in $\mathrm{km}^{2}$ ) of each country, respectively. Also, $P_{d}$ is the population density, i.e., population per unit area (in person per $\mathrm{km}^{2}$ ).

As can be seen, with an increasing population or population density, the number of events, the number of casualties, the number of events per unit area, and the fatality coefficient tend to increase. Due to the nature of the fitted relationships, it can be seen that the rate of increase of these parameters is more severe at first, i.e., for lower values of population, and decreases with increasing population or population density. These relationships can be used as a preliminary approximation in models for predicting and estimating flood losses. 

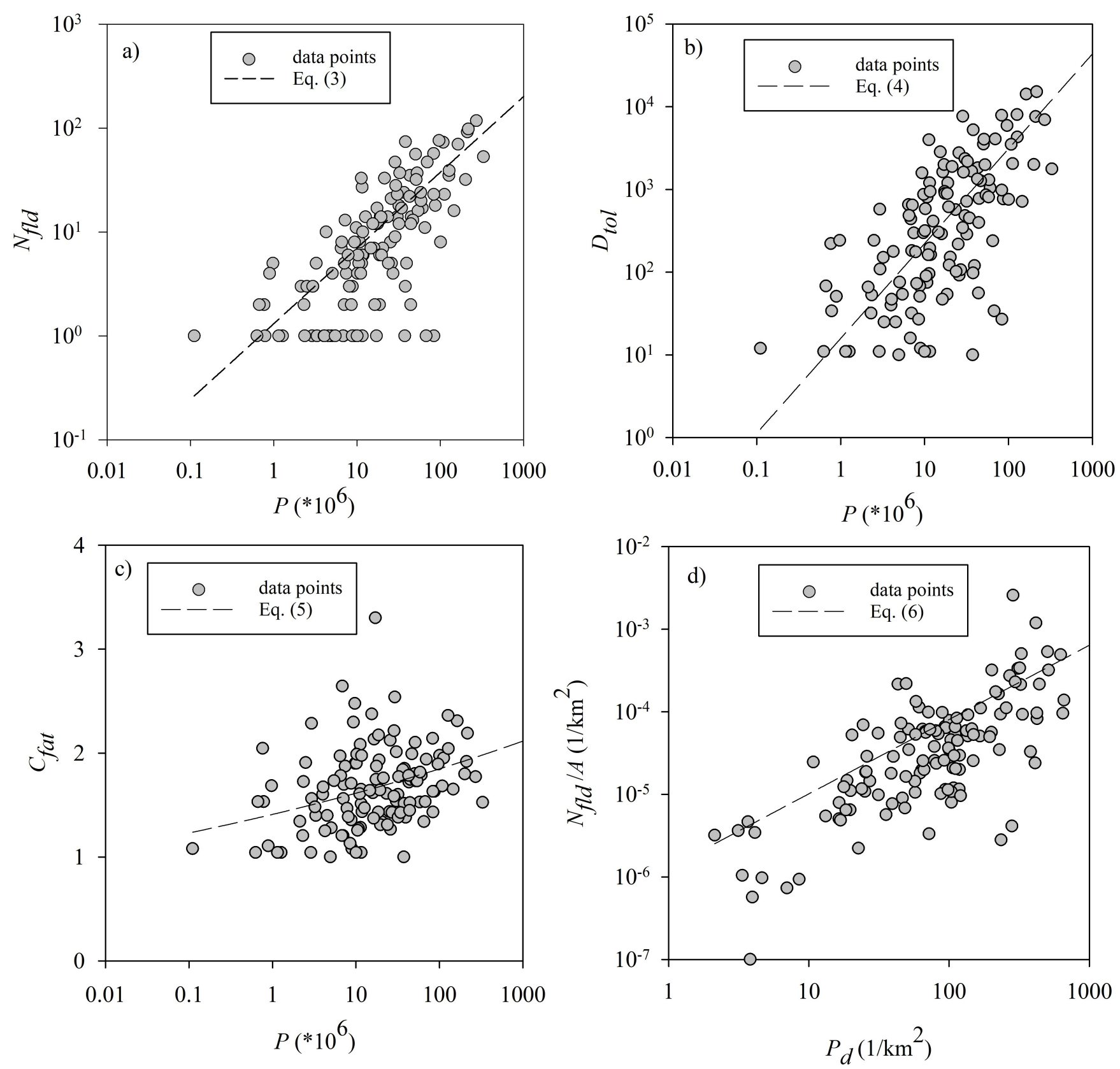

Figure 10. Variations of a) number of flood events, b) total death tolls, and c) fatality coefficient against country population; and d) number of flood events per unit area against population density.

It is worth to remind that the presented results derive from a single database, and are therefore influenced by the data availability. 
Future studies will concentrate on integrating information coming from multiple databases, aiming to obtain more structured and event-based outcomes.

\section{Conclusions}

In this study, the floods that occurred in the 1951-2020 period were investigated. Since floods with fatalities of less than 10 people constitute a small part of the total fatalities, and also the number of floods with death tolls of more than 10,000, the present analysis was limited to events that caused between 10 and 10,000 fatalities, and used the EM-DAT database as a source of information.

The results showed that there is a large difference among the various countries of the world in terms of number of flood events and fatalities. Most floods occur in India, China, Indonesia, Pakistan, Brazil, and Vietnam, while India, China, Pakistan, Bangladesh, Japan, and Iran have the highest flood death tolls. To compare the most vulnerable countries in terms of human fatalities against floods, the flood fatality coefficient was calculated by dividing the number of casualties by the number of flood events. Accordingly, the Netherlands, Lebanon, Yemen, Hungary, India, and Somalia have the highest fatality coefficient. Also, in general, the South, East, and South-East Asia regions are the most vulnerable regions to floods. The study of the temporal changes of floods showed that the number of events has been increasing since the beginning of the period and reached its peak in the 2001-2011 decade, which corresponded to the largest precipitation anomaly in the world. Furthermore, the 1991-2000 decade shows the largest number of fatalities during the last 60 years. Finally, it was found that the number of fatalities per flood event is currently declining, thus indicating the effectiveness of flood control methods, including flood awareness and early warning, which can play an important role in reducing casualties. A direct correlation was found between the number of flood events and the number of casualties with the world's population. The results also demonstated some inconsistencies in GDP growth and its side effects such as flooding.

Data availability. The data used in the research are available in the EM-DAT database www.emdat.be

Author contributions. Conceptualisation, H.H and M.N; Methodology, H.H and M.N; Writing-Original Draft Preparation, H.H and M.N; Writing-Review and Editing, H.H and M.N; Funding Acquisition, M.N.; Both authors have read and agreed to the final version of the manuscript.

Competing interests. The authors declare that they have no competing interests.

Disclaimer. The information reported in this publication reflect only the authors' views 
https://doi.org/10.5194/nhess-2021-357

Preprint. Discussion started: 1 December 2021

(C) Author(s) 2021. CC BY 4.0 License.

(c) (i)

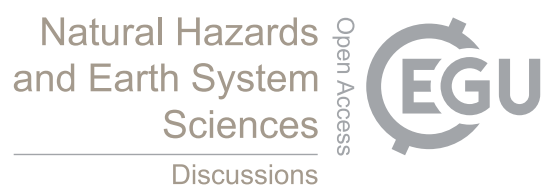

275 Acknowledgements. The work of M.N. was supported within statutory activities No. 3841/E-41/S/2021 of the Ministry of Science and Higher Education of Poland. 


\section{References}

Albright, E. A., and Crow, D.: Beliefs about climate change in the aftermath of extreme flooding. Climatic Change, 155(1), 1-17. https://doi.org/10.1007/s10584-019-02461-2, 2019.

Altez, R., and Revet, S.: Contar los muertos para contar la muerte: discusión en torno al número de fallecidos en la tragedia de 1999 en el estado Vargas-Venezuela. Revista Geográfica Venezolana, 46, 21-43., https://www.redalyc.org/pdf/3477/347730361003.pdf, 2005.

Barendrecht, M.H., Viglione, A., and Blöschl, G.: A dynamic framework for flood risk. Water Security, 1, 3-11. https://doi.org/10.1016/j.wasec.2017.02.001, 2017.

Barredo, J.I.: Normalised flood losses in Europe: 1970-2006. Natural hazards and earth system sciences, 9(1), 97-104, 2009.

Berghuijs, W.R., Aalbers, E.E., Larsen, J.R., Trancoso, R., and Woods, R.A. Recent changes in extreme floods across multiple continents. Environmental Research Letters, 12(11), 114035. https://doi.org/10.1088/1748-9326/aa8847, 2017.

Berz, G.: List of major natural disasters, 1960-1987. Natural Hazards, 1(1), 97-99, 1988.

Blöschl, G., Gaál, L., Hall, J., Kiss, A., Komma, J., Nester, T., ... and Viglione, A.: Increasing river floods: fiction or reality? Wiley Interdisciplinary Reviews: Water, 2(4), 329-344. https://doi.org/10.1002/wat2.1079, 2015.

Bronstert, A.: Floods and climate change: interactions and impacts. Risk Analysis: An International Journal, 23(3), 545-557, 2003.

Clay, E.: The 1974 and 1984 floods in Bangladesh: From famine to food crisis management. Food Policy, 10(3), 202-206. https://doi.org/10.1016/0306-9192(85)90060-0, 1985.

Chen, Y., Syvitski, J.P., Gao, S., Overeem, I., and Kettner, A.J.: Socio-economic impacts on flooding: A 4000-year history of the Yellow River, China. Ambio, 41(7), 682-698. https://doi.org/10.1007/s13280-012-0290-5, 2012.

Criss, R.E. and Shock, E.L.: Flood enhancement through flood control. Geology, 29(10), 875-878, 2001.

Dasgupta, A.: Floods and poverty traps: Evidence from Bangladesh. Economic and Political Weekly, $3166-3171$. https://www.jstor.org/stable/4419847, 2007.

de Bruijn, J. A., de Moel, H., Jongman, B., de Ruiter, M. C., Wagemaker, J., and Aerts, J. C.: A global database of historic and real-time flood events based on social media. Scientific Data, 6(1), 1-12. https://doi.org/10.1038/s41597-019-0326-9, 2019

Dottori, F., Szewczyk, W., Ciscar, J.C., Zhao, F., Alfieri, L., Hirabayashi, Y., ..., and Feyen, L.: Increased human and economic losses from river flooding with anthropogenic warming. Nature Climate Change, 8(9), 781-786. https://doi.org/10.1038/s41558-018-0257-z, 2018.

Dunn, G. E.: The tropical cyclone problem in East Pakistan. Monthly Weather Review, 90(3), 83-86, 1962.

Frank, N. L.: The deadliest tropical cyclone in history?. Bulletin of the American Meteorological Society, 52(6), 438-444, 1971.

Gergel, S.E., Dixon, M.D. and Turner, M.G.: Consequences of human-altered floods: levees, floods, and floodplain forests along the Wisconsin River. Ecological applications, 12(6), 1755-1770, 2002.

Hirabayashi, Y., Mahendran, R., Koirala, S., Konoshima, L., Yamazaki, D., Watanabe, S., Kim, H. and Kanae, S.: Global flood risk under climate change. Nature climate change, 3(9), 816-821, 2013.

Hu, P., Zhang, Q., Shi, P., Chen, B. and Fang, J.: Flood-induced mortality across the globe: Spatiotemporal pattern and influencing factors. Science of The Total Environment, 643, 171-182, 2018.

310 IPCC - Intergovernmental Panel on Climate Change: Summary for Policy Makers, Sixth Assessment Report. Available at https://www.ipcc.ch/report/ar6/wg1/\#SPM, accessed on October 2021.

Jinrong, C. and Zhongshu, H.: Extreme rain and flood in the Yangtze River basin in 1954, Hydrology, 1, 56-62. https://doi.org/10.19797/j.cnki1000-0852.1986.01.013, 1986. 
Jongman, B., Ward, P.J., and Aerts, J.C.: Global exposure to river and coastal flooding: Long term trends and changes. Global Environmental Change, 22(4), 823-835. https://doi.org/10.1016/j.gloenvcha.2012.07.004, 2012.

Kiss, T. and Blanka, V.: River channel response to climate-and human-induced hydrological changes: Case study on the meandering Hernád River, Hungary. Geomorphology, 175, 115-125, 2012.

Kron, W.: Flood risk= hazard•values•vulnerability. Water international, 30(1), 58-68.. https://doi.org/10.1080/02508060508691837, 2005.

Lee, S. and Vink, K.: Assessing the vulnerability of different age groups regarding flood fatalities: Case study in the Philippines, Water Policy, 17(6), 1045-1061, doi:10.2166/wp.2015.089, 2015

Liu, W., Carling, P. A., Hu, K., Wang, H., Zhou, Z., Zhou, L., ... and Zhang, X.: Outburst floods in China: A review. Earth-Science Reviews, 197, 102895. https://doi.org/10.1016/j.earscirev.2019.102895, 2019.

Lopez J.L., Perez D. and Garcia R.: Hydrologic and geomorphologic evaluation of the 1999 debris-flow event in Venezuela. In Proceedings International Conference on Debris-Flow Hazards Mitigation: Mechanics, Prediction, and Assessment 2003 Sep 13 (Vol. 2, pp. 989-1000), 2003

Manfreda, S., Miglino, D., and Albertini, C.: Impact of detention dams on the probability distribution of floods. Hydrology and Earth System Sciences, 25(7), 4231-4242. https://doi.org/10.5194/hess-25-4231-2021, 2021.

Merz, B., Blöschl, G., Vorogushyn, S., Dottori, F., Aerts, J. C., Bates, P., ..., and Macdonald, E.: Causes, impacts and patterns of disastrous river floods. Nature Reviews Earth \& Environment, 1-18. https://doi.org/10.1038/s43017-021-00195-3, 2021.

Mirza, M. M. Q.: The choice of stage-discharge relationship for the Ganges and Brahmaputra rivers in Bangladesh. Hydrology Research, 34(4), 321-342, 2003.

Moniruzzaman, M., Cottrell, A., King, D. and Islam, M. N.: Environmental Migrants in Bangladesh: A Case Study on Climatic Change Hazards in the Southwestern Coastal Area. In Bangladesh I: Climate Change Impacts, Mitigation and Adaptation in Developing Countries (pp. 99-117). Springer, Cham, 2018.

Monowar Hossain, M., Baki, A.B.M. and Ahmad, S.S.: The Flood Problem and Mitigation Methods in Bangladesh. In 4th International Symposium on flood Defense: Managing flood Risk, Reliability and vulnerability. Toronto, Ontario, Canada, 2008.

Munoz, S.E., Giosan, L., Therrell, M.D., Remo, J.W., Shen, Z., Sullivan, R.M., Wiman, C., O’Donnell, M. and Donnelly, J.P.: Climatic control of Mississippi River flood hazard amplified by river engineering. Nature, 556(7699), 95-98, 2018.

Nakagawa, H.: Numerical simulation of sediment disasters caused by heavy rainfall in Camuri Grande basin, Venezuela 1999. In Proceedings of the 3rd Conference on Debris-Flow Hazards Mitigation: Mechanics, Prediction, and Assessment, 2003 (pp. 671-682), 2003.

Nones, M.: Dealing with sediment transport in flood risk management. Acta Geophysica, 67(2), 677-685. https://doi.org/10.1007/s11600019-00273-7, 2019.

Nones, M., and Pescaroli, G.: Implications of cascading effects for the EU Floods Directive. International Journal of River Basin Management, 14(2), 195-204. https://doi.org/10.1080/15715124.2016.1149074, 2016.

Nzunda, E.F. and Midtgaard, F.: Spatial relationship between deforestation and protected areas, accessibility, population density, GDP and other factors in mainland Tanzania. Forests, Trees and Livelihoods, 26(4), 245-255, 2017.

Petrucci, O.: Factors leading to the occurrence of flood fatalities: a systematic review of research papers published between 2010 and 2020. Natural Hazards and Earth System Sciences Discussions, 1-19. https://doi.org/10.5194/nhess-2021-269, 2021.

Pinter, N., Jemberie, A.A., Remo, J.W., Heine, R.A. and Ickes, B.S.: Flood trends and river engineering on the Mississippi River system. Geophysical Research Letters, 35(23), 2008. 
Rasid, H. and Paul, B. K.: Flood problems in Bangladesh: Is there an indigenous solution?. Environmental Management, 11(2), 155-173, 1987.

Ross, A., and Chang, H.: Socio-hydrology with hydrosocial theory: two sides of the same coin?. Hydrological Sciences Journal, 65(9), 1443-1457. https://doi.org/10.1080/02626667.2020.1761023, 2020.

Sheehan, L. and Hewitt, K. (1969), A Pilot Survey of Global Natural Disaster of the Past Twenty Years. Natural Hazard Research Working Paper No. 11, Department of Geography, University of Toronto.

Stuart-Smith, R.F., Roe, G.H., Li, S. and Allen, M.R.: Increased outburst flood hazard from Lake Palcacocha due to human-induced glacier retreat. Nature Geoscience, 14(2), 85-90, 2021.

Takahashi, T., Nakagawa, H., Satofuka, Y., and Kawaike, K.: Flood and sediment disasters triggered by 1999 rainfall in Venezuela: A river restoration plan for an alluvial fan. Journal of Natural Disaster Science, 23(2), 65-82, 2001.

Tanoue, M., Hirabayashi, Y. and Ikeuchi, H.: Global-scale river flood vulnerability in the last 50 years. Scientific reports, 6(1), 1-9, 2016.

Tellman, B., Sullivan, J. A., Kuhn, C., Kettner, A.J., Doyle, C.S., Brakenridge, G.R., ..., and Slayback, D.A.: Satellite imaging reveals increased proportion of population exposed to floods. Nature, 596(7870), 80-86. https://doi.org/10.1038/s41586-021-03695-w, 2021.

Trinh, B. and Quoc, B.: Some problems on the sectoral structure, GDP growth and sustainability of Vietnam. Journal of Reviews on Global Economics, 6, 143-153, 2017.

Turner, B.L., Kasperson, R.E., Matson, P.A., McCarthy, J.J., Corell, R.W., Christensen, L., ,.., and Schiller, A.A.: framework for vulnerability analysis in sustainability science. Proc. National Academy of Sciences, 100(14), 8074-8079. https://doi.org/10.1073/pnas.1231335100, 2003.

UNDRR: Human Cost of Disasters. An Overview of the last 20 years: 2000-2019. https://reliefweb.int/report/world/human-cost-disastersoverview-last-20-years-2000-2019, 2020.

UNISDR: Global Assessment Report on Disaster Risk Reduction, pp. 470, 2019.

van Maren, D. S., Winterwerp, J. C., Wu, B. S., Zhou, J. J., Alves, E. C. T. L., Cardoso, A. H., Leal,J. G. A. B. and Ferreira, R. M. L.: Morphological modelling of hyperconcentrated floods in the Yellow River." In Proceedings of the International Conference on Fluvial Hydraulics: Lisbon, Portugal, London, Taylor and Francis Group, pp. 1383-1392, 2006.

Wang, Z.-Y., and Plate, E. J.: Recent flood disasters in China. Proceedings of the Institution of Civil Engineers - Water and Maritime Engineering, 154(3), 177-188. https://doi.org/10.1680/wame.2002.154.3.177, 2002.

Wasko, C., Nathan, R., Stein, L., and O'Shea, D.: Evidence of shorter more extreme rainfalls and increased flood variability under climate change. Journal of Hydrology, 603(B), 126994. https://doi.org/10.1016/j.jhydrol.2021.126994, 2021.

Ward, P. J., Jongman, B., Weiland, F. S., Bouwman, A., van Beek, R., Bierkens, M. F., ... and Winsemius, H. C.: Assessing flood risk at the global scale: model setup, results, and sensitivity. Environmental Research Letters, 8(4), 044019. https://doi.org/10.1088/17489326/8/4/044019, 2013.

Wieczorek, G. F., Larsen, M. C., Eaton, L. S., Morgan, B. A., and Blair, J. L.: Debris-flow and flooding hazards associated with the December 1999 storm in coastal Venezuela and strategies for mitigation (No. 2001-144). https://doi.org/10.3133/ofr01144, 2001.

Yang, L., Liu, M., Smith, J. A., and Tian, F.: Typhoon Nina and the August 1975 flood over central China. Journal of Hydrometeorology, 18(2), 451-472. https://doi.org/10.1175/JHM-D-16-0152.1, 2017.

Yang, C., Yu, Z., Hao, Z., Zhang, J. and Zhu, J.: Impact of climate change on flood and drought events in Huaihe River Basin, China. Hydrology Research, 43(1-2), 14-22, 2012. 
https://doi.org/10.5194/nhess-2021-357

Preprint. Discussion started: 1 December 2021

(c) Author(s) 2021. CC BY 4.0 License.

(c) (1)

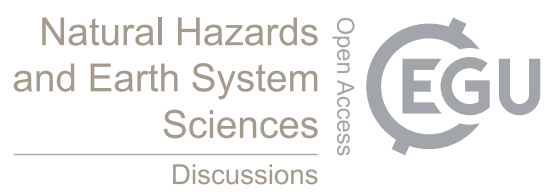

Yari, A., Ostadtaghizadeh, A., Ardalan, A., Zarezadeh, Y., Rahimiforoushani, A. and Bidarpoor, F.: Risk factors of death from flood: Findings of a systematic review, J. Environ. Heal. Sci. Eng., 18(2), 1643-1653, doi:10.1007/s40201-020-00511-x, 2020.

390 Yin, H. and Li, C.: Human impact on floods and flood disasters on the Yangtze River. Geomorphology, 41(2-3), 105-109, 2001.

Zhou, Q., Leng, G., and Feng, L.: Predictability of state-level flood damage in the conterminous United States: the role of hazard, exposure and vulnerability. Scientific Reports, 7(1), 1-11. https://doi.org/10.1038/s41598-017-05773-4, 2017.

Zong, Y., and Chen, X.: The 1998 flood on the Yangtze, China. Natural Hazards, 22(2), 165-184. https://doi.org/10.1023/A:1008119805106, 2000 . 